\title{
MOLECULAR ORIGIN OF SURFACE-ENHANCED RAMAN SPECTRA OF E. COLISUSPENSIONS EXCITED AT 532 AND 785 NM USING SILVER NANOPARTICLE SOLS AS SERS SUBSTRATES
}

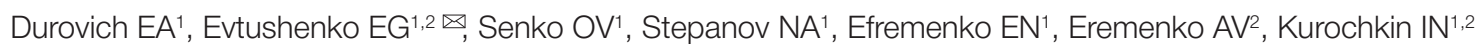 \\ ${ }^{1}$ Faculty of Chemistry, Lomonosov Moscow State University, Moscow \\ 2 Emanuel Institute of Biochemical Physics of RAS, Moscow
}

\begin{abstract}
Research into the molecular origin of surface-enhanced Raman spectra (SERS) of bacteria is a crucial step in assessing the future of SERS-based discrimination and identification of bacteria in clinical analysis, food quality control, etc. Previous studies have revealed that at $785 \mathrm{~nm}$ excitation wavelength SERS of bacterial cells placed on a solid surface functionalized with in-situ grown aggregated gold nanoparticles covered with $\mathrm{SiO}_{2}$ originate from a mixture of 6 purine derivatives (adenine, guanine, AMP, hypoxanthine, xanthine, and uric acid) that are released by the cells into the medium. The aim of the present work was to investigate whether such interpretation is possible with a different class of SERS substrates: silver nanoparticle sols at excitation wavelengths of 785 and $532 \mathrm{~nm}$. The suspension of the Escherichia coli DH5a strain was used as a model bacterium. Sols of silver nanoparticles were obtained by reducing silver nitrate in the presence of alkaline hydroxylamine hydrochloride. Number-weighted mean hydrodynamic diameter of the particles was $43 \pm 2 \mathrm{~nm}$. We confirm that at both excitation wavelengths the spectra can be best described as a superposition of 4 purine derivatives: adenine, guanine, hypoxanthine, and xanthine. Importantly, we have discovered that 1) the spectra of the purine mixture are characteristic of viable cells only; 2) due to the variations in the concentrations of purine metabolites released by the cells into the surrounding medium the spectra of a bacterial strain can vary significantly when a silver nanoparticle sol is used as a SERS substrate.
\end{abstract}

Keywords: SERS of bacteria, E. coli, silver nanoparticles, purines

Correspondence should be addressed: Evgeniy G. Evtushenko

Leninskie gory 1, bl. 3, Moscow, 119991; evtushenko@enzyme.chem.msu.ru

Received: 15.08.2018 Accepted: 09.09.2018

DOI: $10.24075 /$ brsmu.2018.088

\section{МОЛЕКУЛЯРНАЯ ПРИРОДА ГКР-СПЕКТРОВ СУСПЕНЗИИ Е. COLI ПРИ ДЛИНАХ ВОЛН ВОЗБУЖДЕНИЯ 532 И 785 НМ С ИСПОЛЬЗОВАНИЕМ ЗОЛЕЙ НАНОЧАСТИЦ СЕРЕБРА В КАЧЕСТВЕ ГКР-СУБСТРАТОВ}

\author{
Е. А. Дурович ${ }^{1}$, Е. Г. Евтушенко ${ }^{1,2}$, О. В. Сенько ${ }^{1}$, Н. А. Степанов ${ }^{1}$, Е. Н. Ефременко ${ }^{1}$, А. В. Еременко ${ }^{2}$, И. Н. Курочкин ${ }^{1,2}$
}

\footnotetext{
Химический факультет, Московский государственный университет имени М. В. Ломоносова, Москва

${ }^{2}$ Институт биохимической физики имени Н. М. Эмануэля РАН, Москва
}

\begin{abstract}
Вопрос о молекулярной природе спектров гигантского комбинационного рассеяния (ГКР) бактерий является ключевым для оценки перспектив их дискриминации и идентисикации данным методом в целях клинической диагностики, обеспечения безопасности пищевых продуктов и др. Ранее было показано, что при использовании в качестве ГКР-субстрата агрегированных и покрытых слоем $\mathrm{SiO}_{2}$ золотых наночастиц на твердой поверхности источником спектра при длине волны возбуждения 785 нм является смесь шести пуриновых производных (аденина, гуанина, АМФ, гипоксантина, ксантина и мочевой кислоты), выделяемая клетками в раствор. Целью настоящей работы было показать применимость данной интерпретации спектров на примере суспензии клетоK Escherichia coli штамма DH5a для другого класса ГКР-субстратов - золей наночастиц серебра при длинах волн возбуждения 785 и 532 нм. Золи получали восстановлением нитрата серебра хлоридом гидроксиламина в щелочной среде, среднечисловой размер частиц составил $43 \pm 2$ нм. Выявлены две важные особенности: во-первых, спектр пуриновых метаболитов регистрируется только при наличии живых клеток; во-вторых, при использовании золей наночастиц серебра в качестве ГКР-субстрата спектрам даже одного и того же штамма присуща значительная вариативность вследствие изменения соотношения концентраций пуриновых метаболитов, выделяемых клетками в раствор.
\end{abstract}

Ключевые слова: ГКР-спектры бактерий, E. coli, наночастицы серебра, пуриновые производные

$\varangle$ Для корреспонденции: Евгений Геннадиевич Евтушенко

Ленинские горы, д. 1, стр. 3, г. Москва, 119991; evtushenko@enzyme.chem.msu.ru

Статья получена: 15.08.2018 Статья принята к печати: 09.09.2018

DOI: $10.24075 /$ vrgmu.2018.088

Surface-enhanced Raman spectroscopy (SERS) is an optical technique that relies on the amplification of the weak Raman signal emitted by a molecule located in close proximity to a metal surface with nanoscale roughness. Dating back a few decades, SERS still has not lost its appeal as a powerful detection technique. It is rapid and simple in instrumentation; it can be optimized to achieve a very high sensitivity and measure multiple analytes. SERS can also be employed for local analysis. Metal nanostructures used for signal enhancement are referred to as SERS substrates and fall into two major categories: nanostructures on solid supports and colloidal sols of metal nanoparticles. 
SER spectra of bacteria were first recorded at a $514.5 \mathrm{~nm}$ laser excitation wavelength (EW) from Escherichia coli and Bacillus megaterium [1]. It was soon discovered that excitation at 488 or $514.5 \mathrm{~nm}$ results in almost identical SER spectra from gram-positive and gram-negative bacteria, as well as their isolated cell membranes: all acquired spectra originated from reduced or oxidized riboflavin (RF) [2-4]. The RF extinction band overlaps with 488 and $514.5 \mathrm{~nm}$ EWs, which induces resonant enhancement of the RF spectrum [3]. RF is a component of cofactors of redox enzymes and electron transport proteins found in cell membranes. If a bacterial cell is applied onto the surface of a solid SERS substrate or, alternatively, metal nanoparticles are synthesized or absorbed onto the cell, RF will come to occur in close proximity to the metal surface [3, 4]. From a bioanalytical standpoint, it means that laser sources with short wavelengths of 488 and $514.5 \mathrm{~nm}$ cannot be used for the identification of or discrimination between different bacteria.

At the same time, bacterial cells excited at long incident EW $(785 \mathrm{~nm})$ have SER spectra that do not contain the bands characteristic of riboflavin. Moreover, SER spectra vary between bacterial species and sometimes strains, not to mention intact and inactivated samples of the same strain [5-7]. This inspired a hypothesis in the early $21^{\text {st }}$ century about the feasibility of SERS for the identification of bacterial species and strains excited at $785 \mathrm{~nm}$ wavelength. If adopted, this approach would have sped up pathogen detection in patients' samples, food products, and environmental objects. However, the molecular origin of bacterial SER spectra at long EWs was vague. According to a proposed hypothesis, such spectra could originate from the molecules localized in the bacterial glycocalyx (a slime layer or a capsule) or bacterial envelope (a cell wall or a membrane), as was the case with short wavelength lasers. Some authors speculated that the spectra might originate from $\mathrm{N}$-acetyl-D-glucosamine [6], amino acid residues, peptides, protein prosthetic groups, phospholipids, metabolites (such as glucose or acetoacetic acid), or DNA and its constituents (guanine and adenine) [5, 7-13]. However, the proposed hypotheses lacked substance: they interpreted the origin of individual bands only ignoring the full spectra. As a result, this area of science was long dominated by a formal mathematical approach that combined the method of principal component analysis (PCA) used to reduce the dimensionality of experimental data and discriminant or cluster analysis aimed to prove the feasibility of discrimination between bacterial genera, species and strains based on their SER spectra [6, 12-15].

But then a study published in 2016 demonstrated convincingly that it was 6 purine metabolites released into the medium by the bacterial cell that were the source of SER spectra at $785 \mathrm{~nm}$ EW for 10 investigated samples [16]. The purine derivatives included adenine, guanine, adenosine monophosphate, hypoxanthine, xanthine, and uric acid. The suggested interpretation imposes a dramatic limitation on the use of bacterial SER spectra for the identification/ discrimination of pathogens because the differences between their spectra are caused by only 6 secreted purine derivatives and not the whole diversity of molecules on the cell surface. For example, a hypoxanthine-free $E$. coli mutant with a silent adenosine deaminase gene was closer in its SER spectrum to Staphylococcus aureus than to the parent strain. The EW used in that experiment was $785 \mathrm{~nm}$. Aggregated gold nanoparticles grown on a solid surface and coated with a thin silica layer were used as a SERS substrate. The aim of our study was to verify the authors' conclusions using a principally different type of SERS substrates (silver nanoparticle sols) and to investigate the molecular origin of bacterial SER spectra at $532 \mathrm{~nm}$ EW lying between riboflavin-dominated (488 and $514.5 \mathrm{~nm}$ ) and infrared (785 and 1,064 $\mathrm{nm}$ ) spectral regions.

\section{METHODS}

E. coli DH5a (Thermo Fisher Scientific; USA) was used as a model strain. The cells were cultivated in a liquid culture medium consisting of $10.0 \mathrm{~g} / \mathrm{l}$ tryptone (Difco; USA), $5.0 \mathrm{~g} / \mathrm{l}$ yeast extract (Difco; USA) and $10.0 \mathrm{~g} / \mathrm{l}$ chemically pure $\mathrm{NaCl}$ (pH 6.8) (Chimmed; Russia) at $37^{\circ} \mathrm{C}$ for $14-16 \mathrm{~h}$ until the stationary phase was reached. According to the literature [17], the cultured cells should be washed thoroughly to remove the residual components of the culture medium. Bearing that in mind, we applied the following protocol. Briefly, the cells were pelleted in the Beckman J-2-21 centrifuge (Beckman Coulter; USA) at 8,000 rpm for $7 \mathrm{~min}$. The pellet was washed in an equivalent volume of $0.9 \% \mathrm{NaCl}$. The procedure was repeated twice. The obtained biomass was diluted with $0.9 \%$ $\mathrm{NaCl}$ taken at a volume sufficient for obtaining a suspension of $1 \cdot 10^{8}$ cells per $\mathrm{ml}$. The final concentration was determined spectrophotometrically at $540 \mathrm{~nm}$.

For the experiments with partially inactivated bacteria, the suspensions were placed into a water bath preheated to $70^{\circ} \mathrm{C}$ or $90{ }^{\circ} \mathrm{C}$ and kept at this temperature for $1 \mathrm{~h}$. The degree of inactivation was inferred from the concentration of intracellular ATP measured by the luciferase-luciferin assay using the reagent kit and calibration standards by Lumtek; Russia.

A sol of Ag nanoparticles (AgNPs) was used as SERS substrate. The sol was prepared by reducing silver nitrate with hydroxylamine hydrochloride in the presence of sodium hydroxide using $\mathrm{AgNO}_{3}$ (ASC reagent, $\geq 99.0 \%$; Sigma-Aldrich; USA), $\mathrm{NH}_{2} \mathrm{OH} \bullet \mathrm{HCl}$ (purified; Prime Chemicals Group; Russia), and $\mathrm{NaOH}$ (reagent grade; Mosreaktiv; Russia). Following the original protocol [18], the silver nitrate solution was poured into the alkaline hydroxylamine solution. The final concentrations of the reagents in the mixture were $1 \mathrm{mM} \mathrm{AgNO}_{3}, 1.5 \mathrm{mM}$ $\mathrm{NH}_{2} \mathrm{OH} \cdot \mathrm{HCl}$, and $3 \mathrm{mM} \mathrm{NaOH}$. Sols older than 3 days were not used in the experiment.

The absorption spectra of the synthesized nanoparticles were measured in a UV-visible region (300-750 nm) with the cuvette spectrophotometer UV-1800 (Shimadzu; Japan). The size and concentration of AgNPs were measured by nanoparticle tracking analysis (NTA) using the Nanosight LM10 HS-BF system (Nanosight Ltd; UK).

The SER spectra of both intact and inactivated bacteria were recorded on the day of sample preparation. Until then, the samples were stored at $+4{ }^{\circ} \mathrm{C}$. Immediately before the measurement, a sample aliquot was centrifuged twice at 3,700 rpm for $5 \mathrm{~min}$ in the Biofuge A centrifuge (Heraeus Sepatech; Germany) and washed in an equivalent volume of deionized water. The obtained cell suspension in water was mixed with the AgNP sol at a ratio of 1:1 and incubated for $1 \mathrm{~min}$. Then, the $\mathrm{NaCl}$ solution taken at a final concentration of $40 \mathrm{mM}$ was introduced into the mixture to stimulate particle aggregation and enhance the signal. An aliquot of this mixture $(260 \mu \mathrm{ll})$ was transferred into a well of an aluminum wellplate to minimize the background signal and improve heat dissipation. The spectra were measured in 3 to 4 replicates per sample; the samples were stirred by pipetting between measurements.

To study the changes in the SER spectra over time, $5 \mathrm{ml}$ of the $E$. coli suspension were transferred to deionized water following the procedure described above. The obtained water suspension was stored at $+4{ }^{\circ} \mathrm{C}$ and its aliquots were picked 
to register SER spectra over the course of $4 \mathrm{~h}$. The filtrate was prepared by filtering the $E$. coli water suspension slowly using a syringe filter SFNY030022S (Membrane Solutions; USA) with a diameter of $30 \mathrm{~mm}$ and a pore size of $0.22 \mu \mathrm{m}$.

At $785 \mathrm{~nm}$ EW, SER spectra were recorded using the innoRam BWS445(B)-785S spectrometer (BWTek; USA) with a $785 \mathrm{~nm}$ diode laser source and a ×20 PL L 20/0.40 objective. The instrument was operated at a measuring range of $64-3,011 \mathrm{~cm}^{-1}$ and resolution of $4 \mathrm{~cm}^{-1}$. The spectra were recorded using the incident beam power of $42 \mathrm{~mW}, 5 \mathrm{~s}$ signal accumulation time, and averaging over 20 repeated scans. At $532 \mathrm{~nm}$ EW, SER spectra were recorded using the iRaman BWS415-532S spectrometer (BWTek; USA) with a $532 \mathrm{~nm}$ diode laser source and a $\times 20 \mathrm{PL} L$ 20/0.40 objective. The instrument was operated at a measuring range of $174-4,001 \mathrm{~cm}^{-1}$ and resolution of $4 \mathrm{~cm}^{-1}$. The spectra were recorded using the incident beam power of $20 \mathrm{~mW}$; 5 s signal accumulation time, and averaging over 20 repeated scans.

Table. The table shows all spectral bands observed in the SER spectra of $E$. coli including the filtrates of cell suspensions and their assignment to the purine metabolites whose spectra were characterized in [16]. A — adenine, G — guanine, Hx — hypoxanthine, X - xanthine

\begin{tabular}{|c|c|c|c|c|}
\hline \multicolumn{2}{|c|}{$785 \mathrm{~nm}$} & \multicolumn{2}{|c|}{$532 \mathrm{~nm}$} & \multirow[b]{2}{*}{ Assignment } \\
\hline Peak position, $\mathrm{cm}^{-1}$ & $\begin{array}{c}\text { Band frequency in the } \\
\text { spectra, } \%\end{array}$ & Peak position, $\mathrm{cm}^{-1}$ & $\begin{array}{l}\text { Band frequency in the } \\
\text { spectra, \% }\end{array}$ & \\
\hline $502-515$ & 75 & $502-512$ & 50 & $X, G$ \\
\hline \multirow{2}{*}{$522-540$} & \multirow{2}{*}{100} & 526 & 75 & $\mathrm{G}$ \\
\hline & & $549-550$ & 25 & $\mathrm{Hx}, \mathrm{A}$ \\
\hline $561-574$ & 100 & & & $X, G, A$ \\
\hline $621-633$ & 50 & $617-623$ (sh) & 100 & $\mathrm{Hx}, \mathrm{A}, \mathrm{G}$ \\
\hline $653-667$ & 100 & $648-651$ & 100 & $\mathrm{G}, \mathrm{X}, \mathrm{A}$ \\
\hline $680-683$ & 38 & & & $X, A$ \\
\hline $724-735$ & 100 & $721-728$ & 100 & $\mathrm{~A}, \mathrm{Hx}$ \\
\hline \multirow[t]{2}{*}{$780-792$} & 63 & 770 & 25 & $\mathrm{Hx}$ \\
\hline & & 788 & 25 & $A$ \\
\hline \multirow{2}{*}{ 838-842 } & \multirow{2}{*}{38} & 833 & 25 & \multirow{2}{*}{ Tyrosine (?) } \\
\hline & & $848-850$ & 50 & \\
\hline $867-883$ & 63 & $875-878$ & 25 & $\mathrm{G}, \mathrm{X}$ \\
\hline $925-930$ & 38 & & & $\mathrm{Hx}$ \\
\hline 958-966 & 100 & 952-955 & 100 & $\mathrm{X}, \mathrm{G}, \mathrm{Hx}, \mathrm{A}$ \\
\hline $1002-1008$ & 88 & $1000-1006$ & 100 & $\begin{array}{c}\text { Phenylalanine (?), } \mathrm{A}+\mathrm{Hx}+\mathrm{X} \\
\text { interaction (?) }\end{array}$ \\
\hline \multirow[t]{2}{*}{$1027-1033$} & 25 & $1024-1027$ & 100 & $\mathrm{G}, \mathrm{A}, \mathrm{Hx}$ \\
\hline & & $1043-1045$ & 75 & $\mathrm{G}, \mathrm{X}$ \\
\hline $1084-1096$ & 50 & $1085-1095$ & 100 & $\mathrm{Hx}$ \\
\hline $1115-1130$ & 38 & $1129-1140$ & 100 & $\mathrm{X}, \mathrm{G}, \mathrm{A}$ \\
\hline $1157-1160$ & 25 & 1154 & 25 & $\mathrm{Hx}$ \\
\hline $1175-1189$ & 63 & & & $\mathrm{G}, \mathrm{A}$ \\
\hline $1213-1215$ & 25 & $1215-1233$ & 100 & $\mathrm{G}, \mathrm{Hx}, \mathrm{A}$ \\
\hline $1245-1251$ & 50 & 1242 & 25 & $x$ \\
\hline $1267-1276$ & 25 & 1276 & 25 & $\mathrm{G}, \mathrm{A}$ \\
\hline $1310-1315$ & 25 & & & $\mathrm{X}, \mathrm{A}$ \\
\hline \multirow{3}{*}{$1324-1334$} & \multirow{2}{*}{63} & $1322-1325$ & 75 & $\mathrm{Hx}$ \\
\hline & & $1330-1331$ & 50 & $\mathrm{Hx}$ \\
\hline & & 1341 & 25 & A \\
\hline $1362-1380$ & 63 & $1371-1379$ & 100 & $\mathrm{G}, \mathrm{X}, \mathrm{Hx}, \mathrm{A}$ \\
\hline $1389-1390$ & 13 & 1399 & 25 & $\mathrm{X}, \mathrm{Hx}$ \\
\hline $1444-1453$ & 88 & 1444 & 25 & $\mathrm{Hx}, \mathrm{G}, \mathrm{A}$ \\
\hline $1464-1473$ & 75 & $1457-1468$ & 100 & $\mathrm{Hx}, \mathrm{G}, \mathrm{X}, \mathrm{A}$ \\
\hline 1508 & 13 & 1506 & 25 & $\mathrm{~A}+\mathrm{Hx}+\mathrm{X}$ interaction (?) \\
\hline $1528-1534$ & 25 & $1532-1538$ & 100 & $\mathrm{G}, \mathrm{Hx}, \mathrm{K}$ \\
\hline $1568-1578$ & 63 & $1567-1575$ & 50 & $\mathrm{G}, \mathrm{A}$ \\
\hline $1582-1591$ & 25 & 1584-1595 & 25 & $\mathrm{X}, \mathrm{Hx}$ \\
\hline \multirow[b]{2}{*}{ 1630-1721 (broad) } & \multirow[b]{2}{*}{75} & 1646 & 25 & $\mathrm{G}, \mathrm{A}$ \\
\hline & & $1692-1698$ & 100 & $\mathrm{X}, \mathrm{Hx}, \mathrm{G}$ \\
\hline
\end{tabular}


The recorded spectra were processed in OPUS 7.0 (Bruker Optik GmbH; Germany). The data outside the 500-1,800 $\mathrm{cm}^{-1}$ range was discarded, and the baseline was subtracted using the Background correction tool. Smoothing was not applied to determine peak positions and intensity. However, SERS data for plots was smoothened using the Smooth tool with a frame width of $9 \mathrm{~cm}^{-1}$. The spectra were processed using vector normalization for a clear visual representation of qualitative differences. Normalization was not performed when the intensities of the spectra were compared.

\section{RESULTS}

The popular hydroxylamine technique for the synthesis of AgNP sols [18] is simple and reproducible; the sols it yields significantly enhance the spectra emitted by various analytes, including bacterial cells [19-21]. The AgNP sols we prepared were transparent, deep yellowish-brown in color and did not contain any precipitate. They had a broad and intense absorption band in the near UV-blue region corresponding to the localized surface plasmon resonance of AgNPs with a maximum at $407-409 \mathrm{~nm}$ and absorption at this wavelength ranging from 16.5 to 18 (this accounts for 30 -fold dilution with deionized water). The number-weighted mean hydrodynamic diameter of the particles measured by nanoparticle tracking analysis was $43 \pm 2 \mathrm{~nm}$ in three independent AgNP batches. The total particle concentration was $(8.0 \pm 1.7) \cdot 10^{11}$ particles per $\mathrm{ml}$. The synthesized AgNS sols aggregated in $40 \mathrm{mM}$ $\mathrm{NaCl}$ did not have their own SER spectra at both EW except for a broad low-intensity band contributed by aluminum (the material of the plate) in the region between 1,200 and $1,700 \mathrm{~cm}^{-1}$. This band can be totally subtracted during data processing.

The reproducibility of intact $E$. coli SER spectra at $785 \mathrm{~nm}$ EW was tested in a series of different experiment. First, we repeatedly measured the spectra of the same mixture of $E$. coli + AgNPs + NaCl. Second, we measured the spectra of different aliquots of bacterial sample using the same and different AgNP batches. Third, we measured the spectra of independently cultured and isolated E. coli applied onto one and the same AgNP substrate. Repeatedly measured bacterial samples demonstrated good repeatability (Fig. 1A). The SER spectra of independently cultured bacterial samples varied considerably (Fig. 1B). The most significant variations were observed in the following spectral regions: 508-532; 655; 730-734; 958; 1,450; 1,570-1,576 $\mathrm{cm}^{-1}$.

E. coli stored in water at $+4^{\circ} \mathrm{C}$ for $4 \mathrm{~h}$ (Fig. 1C) demonstrated a gradual increase in the total intensity of the SER spectrum over time accompanied by a change in the intensity ratio of its individual bands. For example, the ratio $I_{730} / I_{655}=1.2$ remained constant at all time points, but the ratio $I_{1325} / I_{655}$ monotonously declined from its initial value of 1.6 to 1.0 over the course of $4 \mathrm{~h}$.

The spectra of the intact $E$. coli suspension in water were compared to its filtrate $(0.22 \mu \mathrm{m})$ in order to locate the molecules giving rise to the SER spectra (Fig. 1D). Considering the slow dynamics, the spectra of aliquots of the initial bacterial suspension were recorded before and after filtration. All spectral

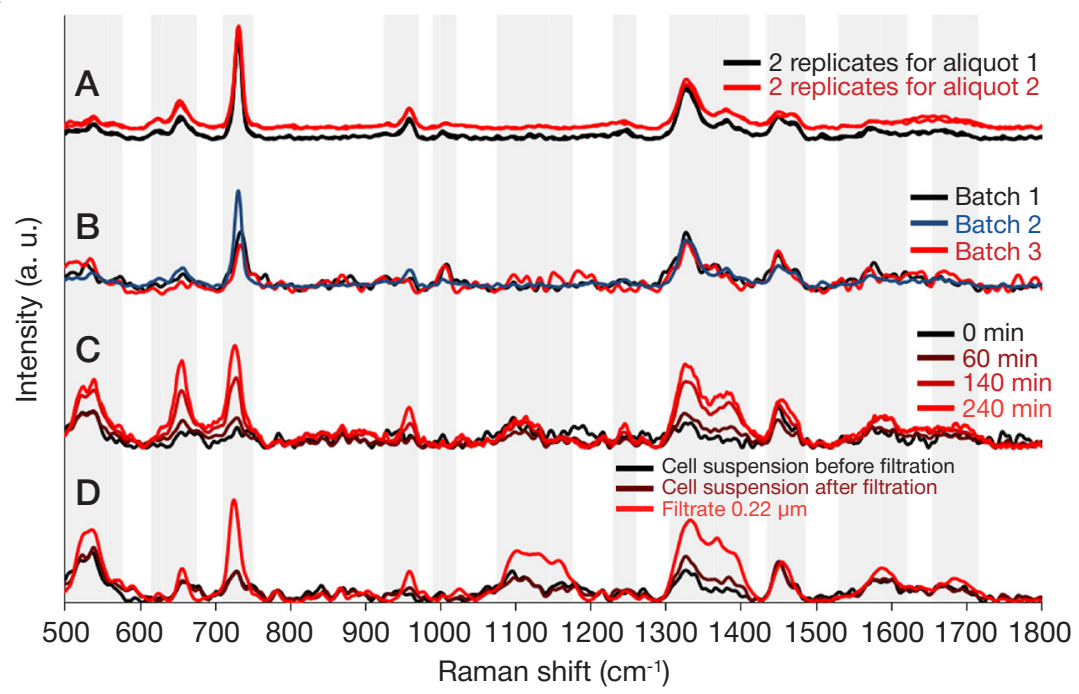

Fig. 1. SER spectra of $E$. coli suspensions at $785 \mathrm{~nm}$ excitation wavelength. A. Repeatability of measurements for one aliquot and one cell batch. B. Reproducibility of the spectra for different batches of cell suspensions. C. Dynamics of SER spectra over time observed in cells stored in water at $+4{ }^{\circ} \mathrm{C}$. D. Comparison of the spectra of the cell suspension and the filtrate $(0.22 \mu \mathrm{m})$ of the same suspension. Vector normalization was applied to the spectra $(\mathbf{A}, \mathbf{B})$; the spectra $(\mathbf{C}, \mathbf{D})$ were not normalized to demonstrate the difference in their intensity. Ranges of spectral differences are shown in gray

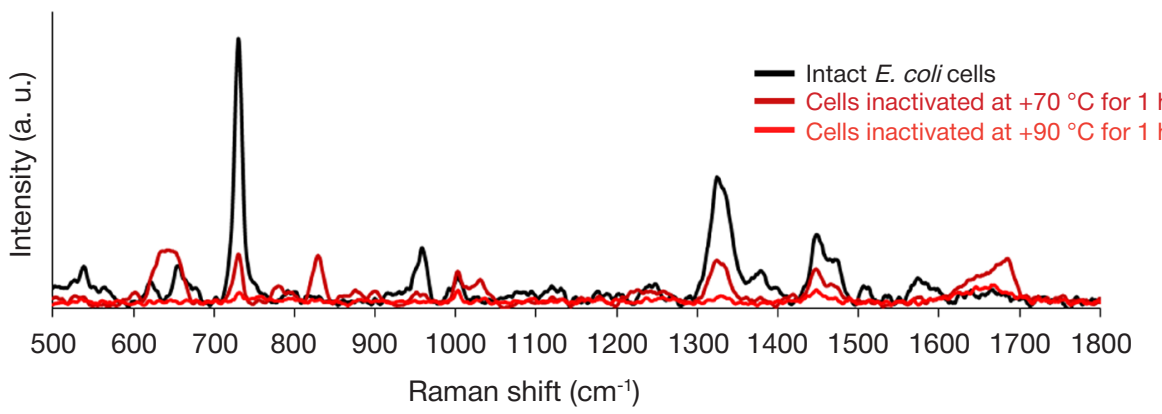

Fig. 2. Changes in the SER spectra of $E$. coli suspensions $(785 \mathrm{~nm})$ following inactivation by heating. The spectra were not normalized to demonstrate the difference in their intensity 
bands observed for the cell suspension were present in the spectra of the filtrate. Moreover, the total intensity of the filtrate spectrum was significantly higher.

The SER spectra of intact cells and those inactivated at $70{ }^{\circ} \mathrm{C}$ or $90^{\circ} \mathrm{C}$ for 60 min were compared in an attempt to understand whether the observed SER spectra can indicate the presence of viable $E$. coli or whether they come from an inactivated bacterial biomass (Fig. 2). The residual concentration of intracellular ATP was also measured in all three sample types (intact bacteria and cells inactivated at $70{ }^{\circ} \mathrm{C}$ and $90{ }^{\circ} \mathrm{C}$ ) as it is indicative of cell viability. The ATP concentrations were $1 \cdot 10^{-9}, 5.6 \cdot 10^{-12}$ and $4.1 \cdot 10^{-12}$ mol per $1 \mathrm{ml}$ of cell suspension, respectively. On the whole, considerable variability was observed in the number and position of spectral bands. However, the total intensity of the spectrum tended to decrease. The spectra of inactivated bacteria $\left(90^{\circ} \mathrm{C}\right)$ contained only 4 very low-intensity bands characteristic of intact $E$. coli $\left(730 ; 1,002 ; 1,325\right.$, and 1,450 $\left.\mathrm{cm}^{-1}\right)$ and two low-intensity bands of the amide III $\left(1,230-1,270 \mathrm{~cm}^{-1}\right)$ and amide I (1,640-1.680 $\left.\mathrm{cm}^{-1}\right)$ regions.

The reproducibility of the SER spectra of intact $E$. coli was also tested at $532 \mathrm{~nm}$ EW. In this case, the intensity of the spectra was twice as high as that observed at $785 \mathrm{~nm}$, resulting in a higher number of informative spectral bands and a better accuracy in locating their position. Similar to $785 \mathrm{~nm}$ EW, at $532 \mathrm{~nm}$ the high repeatability of the spectra was observed for one and the same aliquot of one and the same bacterial sample
(Fig. 3A). But the SER spectra of independently cultured and isolated bacteria varied considerably (Fig. 3B).

\section{DISCUSSION}

Measurements conducted at EW $785 \mathrm{~nm}$ demonstrate that the SER spectra of $E$. coli stored in water are not determined by a single compound, but rather by a mixture of a few different components. This becomes clear when we look at the array of all recorded spectra that contains a fixed set of spectral bands (see the Table). The ratios of the mixture components slowly change over time when cells are stored in water (Fig. 1C) and differ significantly between independently cultured batches of intact cells (Fig. 1B). Comparison of the spectra of the intact bacterial preparation and its filtrate (Fig. 1D) shows that the components of the mixture do not originate from the cell surface but are present in the solution. Moreover, the cell itself can be seen as interfering with the recording of SER spectra, as it adsorbs particles on its surface. This is suggested by a significant increase in the total intensity of the filtrate spectrum in comparison with that of the cell suspension.

Inactivation of bacterial cells demonstrates that the mixture of the compounds in question bears connection to cell viability (Fig. 2) but is not a product of passive desorption from the surface of inactivated cells.

The Table features a list of spectral bands observed in all acquired SER spectra of intact $E$. coli, including the filtrates.

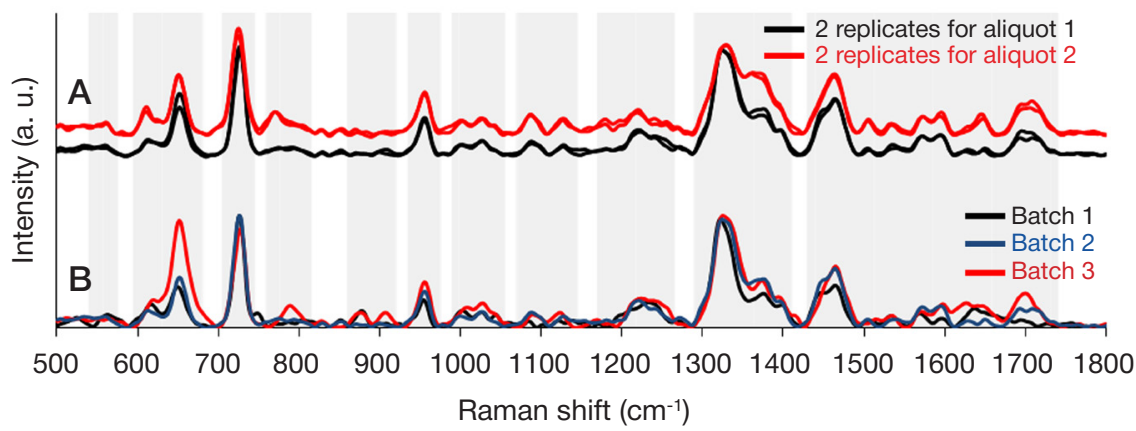

Fig. 3. SER spectra of E. coli suspensions at $532 \mathrm{~nm}$ excitation wavelength A. Repeatability of measurements for one aliquot and one cell batch. B. Reproducibility of the spectra for different batches of cell suspensions. Vector normalization was applied to the spectra. Ranges of spectral differences are shown in gray

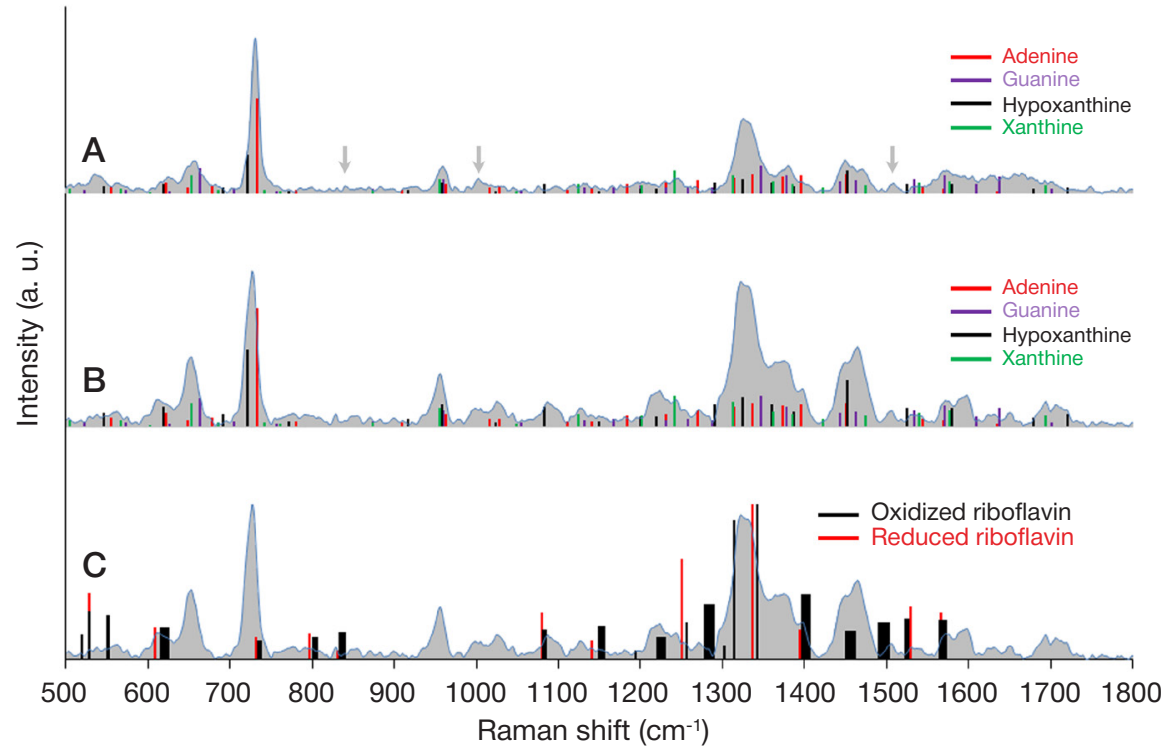

Fig. 4. Overlay of SER spectra corresponding to purine derivatives [16] and riboflavin [4, 24, 25] on the SER spectra of E. coli suspension A. Spectral bands of purine derivatives in the spectra of $E$. coli at $785 \mathrm{~nm}$ EW. Arrows mark uncharacterized low-intensity bands. B. Spectral bands of purine derivatives in the spectra of $E$. coli at $532 \mathrm{~nm}$ EW. C. Overlay of spectral bands of riboflavin on the spectra of $E$. coli at $532 \mathrm{~nm}$ EW. The width of riboflavin bands on the graph reflects the variability of their positions in literature sources 
Upon analyzing the literature, we concluded that at $785 \mathrm{~nm}$ EW almost all spectral bands are a product of superposition of spectra originating from 4 purine derivatives (adenine, guanine, hypoxanthine, and xanthine). This conclusion is consistent with [16]. Besides, for every individual SER spectrum, the intensity and positions of bands correspond to such superposition as well. (Fig. 4A). Unlike the authors of [16] who exploited aggregated gold nanoparticles on a solid surface, we used sols of silver nanoparticles. Considering the possibility of slight variations in the relative intensity of the spectral bands associated with the use of different SER substrates and an increase in intensity following overlay of spectral bands of individual compounds, our description is quite accurate.

Only 3 low-intensity bands remain uncharacterized: 838$842,1,002-1,008$ and $1,508 \mathrm{~cm}^{-1}$. On the one hand, there is a chance that low-intensity bands can be lost during digital conversion of the spectra from literature sources. On the other hands, it is possible that those bands have never been present in the spectra of individual purine derivatives. Then, their origin can be explained by two hypotheses. First, the bands can result from the interactions between the components of the mixture. For example, a SER spectrum of a mixture consisting of adenine, hypoxanthine and xanthine contains two bands $\left(1,000\right.$ and $\left.1,510 \mathrm{~cm}^{-1}\right)$ absent in the individual spectra of its constituents [22]. Besides, the presence of 838-842 and $1,002 \mathrm{~cm}^{-1}$ bands can be explained by minor presence of tyrosine (the most intense spectral bands are 824; 847; 928; 1,$046 ; 1,389$ and $1,583 \mathrm{~cm}^{-1}$ [23]) and phenylalanine (the most intense spectral bands are 930; 1,002; 1,031; 1,394; and $1,602 \mathrm{~cm}^{-1}$ [23]).

The suggested origin of bacterial SER spectra explains a considerable variation in the position of peaks observed for some bands within E. coli spectra. Thus, the variability in the position of the peak of a broad multicomponent band ranging from 502 to $574 \mathrm{~cm}^{-1}$ can be explained by an overlap of the following bands: xanthine $\left(508 \mathrm{~cm}^{-1}\right)$, guanine $\left(526 \mathrm{~cm}^{-1}\right)$, hypoxanthine $\left(550 \mathrm{~cm}^{-1}\right)$, adenine $\left(558 \mathrm{~cm}^{-1}\right)$, and guanine $\left(577 \mathrm{~cm}^{-1}\right)$. For the band in the region between 653 and $667 \mathrm{~cm}^{-1}$, the contributing bands are $652 \mathrm{~cm}^{-1}$ (adenine), $657 \mathrm{~cm}^{-1}$ (xanthine) and $667 \mathrm{~cm}^{-1}$ (guanine); for the 724-735 $\mathrm{cm}^{-1}$ band, $725 \mathrm{~cm}^{-1}$ (hypoxanthine) and $734 \mathrm{~cm}^{-1}$ (adenine); for the broad double band with peaks at 1,444-1,452 $\mathrm{cm}^{-1}$ and 1,464$1,473 \mathrm{~cm}^{-1}$, the contribution is made by guanine $\left(1447 \mathrm{~cm}^{-1}\right)$, adenine $\left(1455 \mathrm{~cm}^{-1}\right)$, hypoxanthine $\left(1456 \mathrm{~cm}^{-1}\right)$, guanine $\left(1466 \mathrm{~cm}^{-1}\right)$, and xanthine $\left(1478 \mathrm{~cm}^{-1}\right)$.

The SER spectra of $E$. coli are very similar at 785 and 532 nm EW (Fig. 4A, 4B) with regards to the position and intensity of some of their constituting bands (Fig. 1B, 3B). This finding encouraged us to describe the acquired SER spectra at EW
$532 \mathrm{~nm}$ as representing a mixture of 4 purine metabolites (adenine, guanine, hypoxanthine, and xanthine) as well. The reference spectra characterized in [16] differ from the acquired E. coli spectra in the type of the SER substrate used and EW, resulting in slight shifts in band positions. Considering that, our description of the experimental SER spectra of E.coli at EW $532 \mathrm{~nm}$ can be characterized as satisfactory.

We also explored a possibility of ascribing the bands in the SER spectra of E. coli at $532 \mathrm{~nm}$ EW to reduced or oxidized riboflavin and FAD whose reference spectra were borrowed from some early works [4, 24, 25] (Fig. 4C). A few high and medium intensity bands of $E$. coli are absent in the SER spectra of RF including 650, 725-733, 955, and 1,365 $\mathrm{cm}^{-1}$. In turn, the SER spectra of $E$. coli either miss a number of RF bands or include the bands with a strongly different intensity: 528$529,834-839,1,149-1,156,1,279-1,289,1,491-1,502$, and $1,523-1,527 \mathrm{~cm}^{-1}$ for oxidized RF and 528, 1,251, 1,501 and $1,530 \mathrm{~cm}^{-1}$ for reduced RF. Nevertheless, the contribution of the RF to the $E$. coli spectra at $532 \mathrm{~nm}$ EW cannot be ruled out. It could additionally increase the intensity of a broad band in the region between 1,300 and $1,350 \mathrm{~cm}^{-1}$ in comparison with the mixture of purine derivatives. However, RF does not dominate the spectrum. This somewhat contradicts the early conclusions about its dominance in the spectra of Pseudomonas aeruginosa, Bacillus subtilis, and Geobacillus stearothermophilus at $532 \mathrm{~nm}$ [25]. Such discrepancy can be explained by the difference in the used bacteria species. To sum up, the SER spectra of E. coli at $532 \mathrm{~nm}$ EW can be best described as a superposition of the spectra of purine derivatives. Similarly to $785 \mathrm{EW}$, the variability of the spectra of bacterial samples from different batches at $532 \mathrm{~nm}$ EW results from the difference in the concentrations of these compounds released by the cells into the solution.

\section{CONCLUSIONS}

The SER spectra of $E$. coli excited at 785 and $532 \mathrm{~nm}$ originate from a mixture of purine derivatives released by the cells into the solution, given that a silver nanoparticle sol synthesized following the hydroxylamine technique is used as a SERS substrate. For both excitation wavelengths, the acquired spectra are best described as originating from adenine, guanine, hypoxanthine, and xanthine. Riboflavin may slightly contribute to the spectra excited at $532 \mathrm{~nm}$. The acquired spectra are characteristic of viable bacteria cells only. Their variability results from the differences in the ratio of the contributing components. Such molecular origin of bacterial SER spectra imposes serious limitations on the use of SERS for bacterial identification and discrimination.

\section{References}

1. Efrima S, Bronk BV. Silver Colloids Impregnating or Coating Bacteria. J Phys Chem B. 1998; 102 (31): 5947-50.

2. Zeiri L, Bronk BV, Shabtai Y, Czégé J, Efrima S. Silver metal induced surface enhanced Raman of bacteria. Colloids Surfaces A Physicochem Eng Asp. 2002; 208 (1): 357-62.

3. Picorel R, Lu T, Holt RE, Cotton TM, Seibert M. Surface-Enhanced Resonance Raman Scattering (SERRS) Spectroscopy of Bacterial Membranes: The Flavoproteins. In: Baltscheffsky $M$, editor. Current Research in Photosynthesis: Proceedings of the VIIIth International Conference on Photosynthesis; 1989 Aug 6-11; Stockholm, Sweden. Dordrecht: Springer Netherlands, 1990; p. 1867-70

4. Zeiri L, Bronk BV, Shabtai Y, Eichler J, Efrima S. Surface-Enhanced Raman Spectroscopy as a Tool for Probing Specific Biochemical Components in Bacteria. Appl Spectrosc. 2004; 58 (1): 33-40.

5. Guzelian AA, Sylvia JM, Janni JA, Clauson SL, Spencer KM. SERS of whole-cell bacteria and trace levels of biological molecules. Proc. SPIE, Vibrational Spectroscopy-Based Sensor Systems. 2002; (4577): 183-92.

6. Jarvis RM, Goodacre R. Discrimination of Bacteria Using SurfaceEnhanced Raman Spectroscopy. Anal Chem. 2004; 76 (1): 40-7.

7. Premasiri WR, Moir DT, Klempner MS, Krieger N, Jones G, Ziegler LD. Characterization of the Surface Enhanced Raman Scattering (SERS) of Bacteria. J Phys Chem B. 2005; 109 (1): 312-20. 
8. Luo BS, Lin M. A Portable Raman System for the Identification of Foodborne Pathogenic Bacteria. J Rapid Methods Autom Microbiol. 2008; 16 (3): 238-55.

9. Kahraman M, Keseroğlu K, Çulha M. On sample preparation for surface-enhanced Raman scattering (SERS) of bacteria and the source of spectral features of the spectra. Appl Spectrosc. 2011; 65 (5): 500-6.

10. Feng J, de la Fuente-Núñez C, Trimble MJ, Xu J, Hancock REW, Lu X. An in situ Raman spectroscopy-based microfluidic "lab-on-a-chip" platform for non-destructive and continuous characterization of Pseudomonas aeruginosa biofilms. Chem Commun. 2015; 51 (43): 8966-9.

11. Su L, Zhang P, Zheng D, Wang Y, Zhong R. Rapid detection of Escherichia coli and Salmonella typhimurium by surface-enhanced Raman scattering. Optoelectron Lett. 2015; 11 (2): 157-160.

12. Mosier-Boss AP. Review on SERS of Bacteria. Biosensors. 2017; 7 (4): $51-76$

13. Witkowska E, Korsak D, Kowalska A, Janeczek A, Kamińska A. Strain-level typing and identification of bacteria - a novel approach for SERS active plasmonic nanostructures. Anal Bioanal Chem. 2018; 410 (20): 5019-31.

14. Patel IS, Premasiri WR, Moir DT, Ziegler LD. Barcoding bacterial cells: a SERS-based methodology for pathogen identification. J Raman Spectrosc. 2008; 39 (11): 1660-72.

15. Sundaram J, Park B, Hinton A, Lawrence KC, Kwon Y. Detection and differentiation of Salmonella serotypes using surface enhanced Raman scattering (SERS) technique. J Food Meas Charact. 2013; 7 (1): 1-12.

16. Premasiri WR, Lee JC, Sauer-Budge A, Théberge R, Costello CE, Ziegler LD. The biochemical origins of the surface-enhanced Raman spectra of bacteria: a metabolomics profiling by SERS. Anal Bioanal Chem. 2016; 408 (17): 4631-47.

17. Marotta NE, Bottomley LA. Surface-Enhanced Raman Scattering of Bacterial Cell Culture Growth Media. Appl Spectrosc. 2010; 64 (6): 601-6.

18. Leopold N, Lendl B. A New Method for Fast Preparation of Highly Surface-Enhanced Raman Scattering (SERS) Active Silver Colloids at Room Temperature by Reduction of Silver Nitrate with Hydroxylamine Hydrochloride. J Phys Chem B. 2003; 107 (24): 5723-7.

19. Cañamares MV, Garcia-Ramos JV, Sanchez-Cortes S, Castillejo M, Oujja M. Comparative SERS effectiveness of silver nanoparticles prepared by different methods: A study of the enhancement factor and the interfacial properties. J Colloid Interface Sci. 2008; 326 (1): 103-9.

20. Knauer M, Ivleva NP, Niessner R, Haisch C. Optimized Surface-enhanced Raman Scattering (SERS) Colloids for the Characterization of Microorganisms. Anal Sci. 2010; 26 (7): 761-6.

21. Félix-Rivera H, González R, Rodríguez GDM, Primera-Pedrozo OM, Ríos-Velázquez C, Hernández-Rivera SP. Improving SERS Detection of Bacillus thuringiensis Using Silver Nanoparticles Reduced with Hydroxylamine and with Citrate Capped Borohydride. Int J Spectrosc. 2011; Article ID 989504.

22. Ranc V, Hruzikova J, Maitner K, Prucek R, Milde D, Kvítek L. Quantification of purine basis in their mixtures at femto-molar concentration levels using FT-SERS. J Raman Spectrosc. 2011; 43 (8): 971-6.

23. Kim SK, Kim MS, Suh SW. Surface-enhanced Raman scattering (SERS) of aromatic amino acids and their glycyl dipeptides in silver sol. J Raman Spectrosc. 1987; 18 (3): 171-5.

24. Kazanci M, Schulte JP, Douglas C, Fratzl P, Pink D, SmithPalmer T. Tuning the Surface-Enhanced Raman Scattering Effect to Different Molecular Groups by Switching the Silver Colloid Solution pH. Appl Spectrosc. 2009; 63 (2): 214-3.

25. Smith-Palmer T, Douglas C, Fredericks P. Rationalizing the SER spectra of bacteria. Vib Spectrosc. 2010; 53 (1): 103-6.

\section{Литература}

1. Efrima S, Bronk BV. Silver Colloids Impregnating or Coating Bacteria. J Phys Chem B. 1998; 102 (31): 5947-50.

2. Zeiri L, Bronk BV, Shabtai $Y$, Czégé J, Efrima S. Silver metal induced surface enhanced Raman of bacteria. Colloids Surfaces A Physicochem Eng Asp. 2002; 208 (1): 357-62.

3. Picorel R, Lu T, Holt RE, Cotton TM, Seibert M. Surface-Enhanced Resonance Raman Scattering (SERRS) Spectroscopy of Bacterial Membranes: The Flavoproteins. In: Baltscheffsky $M$, editor Current Research in Photosynthesis: Proceedings of the VIIIth International Conference on Photosynthesis; 1989 Aug 6-11; Stockholm, Sweden. Dordrecht: Springer Netherlands, 1990; p. 1867-70.

4. Zeiri L, Bronk BV, Shabtai Y, Eichler J, Efrima S. Surface-Enhanced Raman Spectroscopy as a Tool for Probing Specific Biochemical Components in Bacteria. Appl Spectrosc. 2004; 58 (1): 33-40.

5. Guzelian AA, Sylvia JM, Janni JA, Clauson SL, Spencer KM. SERS of whole-cell bacteria and trace levels of biological molecules. Proc. SPIE, Vibrational Spectroscopy-Based Sensor Systems. 2002; (4577): 183-92.

6. Jarvis RM, Goodacre R. Discrimination of Bacteria Using SurfaceEnhanced Raman Spectroscopy. Anal Chem. 2004; 76 (1): 40-7.

7. Premasiri WR, Moir DT, Klempner MS, Krieger N, Jones G, Ziegler LD. Characterization of the Surface Enhanced Raman Scattering (SERS) of Bacteria. J Phys Chem B. 2005; 109 (1): 312-20.

8. Luo BS, Lin M. A Portable Raman System for the Identification of Foodborne Pathogenic Bacteria. J Rapid Methods Autom Microbiol. 2008; 16 (3): 238-55.

9. Kahraman M, Keseroğlu K, Çulha M. On sample preparation for surface-enhanced Raman scattering (SERS) of bacteria and the source of spectral features of the spectra. Appl Spectrosc. 2011; 65 (5): 500-6.

10. Feng J, de la Fuente-Núñez C, Trimble MJ, Xu J, Hancock REW, Lu X. An in situ Raman spectroscopy-based microfluidic "lab-on-a-chip" platform for non-destructive and continuous

characterization of Pseudomonas aeruginosa biofilms. Chem Commun. 2015; 51 (43): 8966-9.

11. Su L, Zhang P, Zheng D, Wang Y, Zhong R. Rapid detection of Escherichia coli and Salmonella typhimurium by surface-enhanced Raman scattering. Optoelectron Lett. 2015; 11 (2): 157-160.

12. Mosier-Boss AP. Review on SERS of Bacteria. Biosensors. 2017; 7 (4): 51-76.

13. Witkowska E, Korsak D, Kowalska A, Janeczek A, Kamińska A. Strain-level typing and identification of bacteria - a novel approach for SERS active plasmonic nanostructures. Anal Bioanal Chem. 2018; 410 (20): 5019-31.

14. Patel IS, Premasiri WR, Moir DT, Ziegler LD. Barcoding bacterial cells: a SERS-based methodology for pathogen identification. J Raman Spectrosc. 2008; 39 (11): 1660-72.

15. Sundaram J, Park B, Hinton A, Lawrence KC, Kwon Y. Detection and differentiation of Salmonella serotypes using surface enhanced Raman scattering (SERS) technique. J Food Meas Charact. 2013; 7 (1): 1-12.

16. Premasiri WR, Lee JC, Sauer-Budge A, Théberge R, Costello CE, Ziegler LD. The biochemical origins of the surface-enhanced Raman spectra of bacteria: a metabolomics profiling by SERS. Anal Bioanal Chem. 2016; 408 (17): 4631-47.

17. Marotta NE, Bottomley LA. Surface-Enhanced Raman Scattering of Bacterial Cell Culture Growth Media. Appl Spectrosc. 2010; 64 (6): 601-6.

18. Leopold N, Lendl B. A New Method for Fast Preparation of Highly Surface-Enhanced Raman Scattering (SERS) Active Silver Colloids at Room Temperature by Reduction of Silver Nitrate with Hydroxylamine Hydrochloride. J Phys Chem B. 2003; 107 (24): 5723-7.

19. Cañamares MV, Garcia-Ramos JV, Sanchez-Cortes S, Castillejo M, Oujja M. Comparative SERS effectiveness of silver nanoparticles prepared by different methods: A study of the enhancement factor and the interfacial properties. J Colloid Interface Sci. 2008; 
326 (1): 103-9

20. Knauer M, Ivleva NP, Niessner R, Haisch C. Optimized Surface-enhanced Raman Scattering (SERS) Colloids for the Characterization of Microorganisms. Anal Sci. 2010; 26 (7): 761-6.

21. Félix-Rivera $H$, González R, Rodríguez GDM, Primera-Pedrozo OM, Ríos-Velázquez C, Hernández-Rivera SP. Improving SERS Detection of Bacillus thuringiensis Using Silver Nanoparticles Reduced with Hydroxylamine and with Citrate Capped Borohydride. Int J Spectrosc. 2011; Article ID 989504.

22. Ranc V, Hruzikova J, Maitner K, Prucek R, Milde D, Kvítek L. Quantification of purine basis in their mixtures at femto-molar concentration levels using FT-SERS. J Raman Spectrosc. 2011; 43 (8): 971-6.

23. Kim SK, Kim MS, Suh SW. Surface-enhanced Raman scattering (SERS) of aromatic amino acids and their glycyl dipeptides in silver sol. J Raman Spectrosc. 1987; 18 (3): 171-5.

24. Kazanci M, Schulte JP, Douglas C, Fratzl P, Pink D, SmithPalmer T. Tuning the Surface-Enhanced Raman Scattering Effect to Different Molecular Groups by Switching the Silver Colloid Solution pH. Appl Spectrosc. 2009; 63 (2): 214-3.

25. Smith-Palmer T, Douglas C, Fredericks P. Rationalizing the SER spectra of bacteria. Vib Spectrosc. 2010; 53 (1): 103-6. 